\title{
Efficacy Of Inhaled Corticosteroids For Patients With Asthma: A Descrip- tive Review Of Randomized Controlled Trials
}

\author{
Mostafa Alabousi, BHSc${ }^{1}$, Abdullah Alabousi, BHSc, MD², Natalie Ambeault, BScPHM, RPh, CDE, \\ John Riva, DC, MSc ${ }^{3}$ \\ ${ }^{1}$ Faculty of Medicine, University of Ottawa \\ 2Department of Radiology, McMaster University \\ ${ }^{3}$ Department of Family Medicine, McMaster University
}

A BSTRACT

Objective: To evaluate the efficacy of inhaled corticosteroids (ICS) in patients with asthma based on changes in sputum eosinophil counts, through a review of relevant randomized controlled trials (RCTs).

Methods: Studies were retrieved from MEDLINE, EMBASE, the SYSTEM FOR INFORMATION ON GREY LITERATURE, and the INSTITUTE FOR SCIENTIFIC INFORMATION from February 1, 2003 to February 1, 2013 based on a comprehensive search strategy. Articles were screened through two stages: title and abstract, and full-text screening. Inclusion criteria included: RCT-type study, asthma population, ICS intervention, and change in sputum eosinophils as an outcome. Exclusion criteria included: other therapies combined with ICS, allergen challenge within intervention, and non-English studies. Following screening, data extraction, and quality appraisal, a descriptive synthesis of trials was conducted.

Results: The search strategy retrieved 447 articles, of which 66 underwent full-text screening, and of which 37 RCTs met the inclusion criteria. The included articles utilized the following types of ICS: budesonide, fluticasone propionate, ciclesonide, beclomethasone dipropionate, and mometasone. Of 46 intervention groups across the trials, 22 demonstrated a statistically significant $(p<0.05)$ reduction in sputum eosinophil counts.

Conclusion: There is insufficient evidence to suggest the superiority of one ICS treatment over another. Further research needs to be conducted to evaluate the relative impact of ICS products upon eosinophil counts, as well as clarify what measurable change in baseline eosinophil counts is required to observe a change in symptom improvement and disease control.

\section{RÉSUMÉ}

Objectif: évaluer l'efficacité des corticostéroïdes inhalés (CSI) chez les patients souffrant d'asthme en fonction des changements dans les numérations d'éosinophiles des expectorations, par une revue d'essais contrôlés randomisés (ECR) pertinents.

Méthodes: Des études ont été récupérés à partir de MEDLINE, EMBASE, le SYSTEM FOR INFORMATION ON GREY LITERATURE, et I'INSTITUTE FOR SCIENTIFIC INFORMATION du 1er février 2003 au 1er février 2013, par le biais d'une stratégie de recherche exhaustive. Les articles ont été examinés en deux étapes: par titre et résumé, et par consultation du texte intégral. Les critères d'inclusion incluent: une étude de type ECR, une population avec asthme, une intervention avec CSI, et un changement dans les éosinophiles d'expectorations en tant que résultat. Les critères d'exclusion incluent: d'autres thérapies combinées avec les CSI, une provocation allergénique durant l'intervention, et des études de langues autres que l'anglais. Après le dépistage, l'extraction de données et l'évaluation de la qualité, une synthèse descriptive des études a été menée.

Résultats: La stratégie de recherche a récupéré 447 articles, dont 66 ont subi un dépistage en texte intégral, et dont 37 ECR ont répondu aux critères d'inclusion. Les articles utilisés ont utilisé les types de CSI suivants: budésonide, propionate de fluticasone, ciclésonide, dipropionate de béclométhasone et mométasone. Parmi les 46 groupes d'intervention entre les études, 22 d'entre eux ont démontré une réduction statistiquement significative $(p<0,05)$ des éosinophiles des expectorations.

Conclusion: II n'existe pas suffisamment de preuves pour suggérer la supériorité d'un traitement par CSI par rapport à un autre. D’autres études doivent être menées pour évaluer l'impact relatif des produits de CSI sur le compte d'éosinophiles, ainsi que pour clarifier quel changement mesurable des éosinophiles de base est nécessaire pour observer un changement dans l’amélioration des symptômes et dans le contrôle de la maladie.

Keywords: Asthma; sputum eosinophils; inhaled corticosteroids; chronic disease management 


\section{BACKGROUND}

Asthma is characterized by variable airflow limitation, which is detected by measurements of airway responsiveness such as spirometry [1]. This pulmonary disease is also associated with airway inflammation, which is manifested by an increased number of eosinophils in the bronchial tissues and secretions [2]. Inhaled corticosteroids (ICS) are considered first-line anti-inflammatory therapy for asthmatic patients [3]. These ICS act to alter gene production involved in the inflammatory process, reducing the synthesis of inflammatory proteins and cytokines. Corticosteroid therapy has been shown to reduce the number of inflammatory cells and their inflammatory action, basement membrane thickness and airway hyperresponsiveness [4].

The most comprehensive, non-invasive method of measuring the severity of airway inflammation is through induced sputum cell count analysis. Specifically, the sputum induction technique is common, and reported as reliable, and valid [5]. Moreover, sputum eosinophilia, recognized as a trademark of asthma evaluation, has been shown to predict the response to corticosteroid treatment. Generally, sputum eosinophil counts decline within three to seven days following the initiation of ICS in the majority of patients requiring treatment [6]. As a result, induced sputum cell counts for management of asthma are more frequently used. Clinical studies have found that using ICS treatments to cause sputum eosinophil counts to fall within a normal range resulted in significant reductions in asthmatic exacerbations. Evidently, sputum cell count analysis can play a prominent role in optimizing the management of asthma in clinical practice [6].

The most recent reviews conducted by Rank et al. [7] and Gan et al.[8] both investigated the use of ICS in asthma and chronic obstructive pulmonary disease, respectively. However, there are gaps left by studies in the literature that this review will bridge. Specifically, there have not been any published systematic reviews specifically investigating the effects of ICS on sputum eosinophils in patients with asthma.

The primary goal of this review is to evaluate the efficacy of ICS in patients with asthma based on changes in sputum eosinophil counts through a review of relevant randomized controlled trials (RCTs) over the past 10 years.

\section{METHODS}

\section{Eligibility Criteria and Literature Search}

The Preferred Reporting Items for Systematic Reviews and Meta-Analyses (PRISMA) guidelines were followed for this review, although our protocol was not registered [9]. Prior to article retrieval, a comprehensive search strategy was developed in conjunction with a research librarian for the purpose of identifying all relevant studies. A search was conducted with the proposed strategy to identify randomized controlled trials (RCTs) involving patients with asthma, of any age, placed on an inhaled corticosteroid (ICS) intervention. RCTs including an ICS intervention in combination with other concurrent treatments were not included, as the purpose of the review is to solely investigate the specific effect of ICS on asthma patients. Studies included in the review were also required to conduct sputum induction as a part of their procedure, and more specifically to report on the change in sputum eosinophil count pre- and post-intervention, as this was the main outcome of the primary objective of this study. Studies measuring the effect of ICS on patients with asthma following an allergen challenge were excluded as the presence of the allergen challenge was a confounding factor to our outcome of interest, resulting in increased sputum eosinophils. Finally, non-English articles were excluded, as translators were not recruited for this project. In summary, inclusion criteria for the review included the following: RCT-type study, asthma population, ICS intervention, and change in sputum eosinophils as an outcome. Moreover, exclusion criteria for the review included the following: other therapies combined with ICS, allergen challenge within intervention, and non-English studies.

The review was conducted on English-language articles found through searches of MEDLINE, EMBASE, the SYSTEM FOR INFORMATION ON GREY LITERATURE (SIGLE), and the INSTITUTE FOR SCIENTIFIC INFORMATION (ISI). The search was conducted from February 1, 2003 to February 1, 2013. Only RCTs conducted in the past 10 years were included in order to strictly investigate the most recent ICS interventions being used to treat patients with asthma. To ensure that a comprehensive search strategy was being used for these databases, several different variations of the strategy were tested to investigate any potential changes in the number of retrieved articles. The search strategies tested can be found in Supporting Information S1.

\section{Study Selection}

Following the removal of duplicate articles, two reviewers (MA \& AA) independently evaluated the eligibility of all of the retrieved articles that resulted from executing the search strategy. A pilot-tested screening form (found in Supporting Information S1) was developed for evaluating the retrieved studies. This form outlined the criteria that each article had to meet to move on to subsequent stages of screening, and finally, to data extraction. The first stage of screening conducted by the reviewers involved title and abstract review. Articles that moved forward to the next stage of screening either fulfilled all three criteria outlined, or did not present enough information in their title and abstract to be evaluated based on the screening form. The three criteria were the following: the study involves sputum induction and reports eosinophil count as an outcome; the study is an RCT with human subjects; and, the study investigates patients with asthma undergoing an ICS treatment. During the second stage of screening, the reviewers conducted a full-text review of the 
articles that had passed the first level. Once again, each article was evaluated based on the criteria of the screening form. Articles that met all three criteria moved forward to the data extraction stage. Disagreement was resolved by consensus at each stage of screening. Chance-corrected pre-consensus agreement was measured at both the title and abstract as well as full text screening stages using the kappa statistic. Values of 0 to 0.20 represented slight agreement, 0.21 to 0.40 represented fair agreement, 0.41 to 0.60 represented moderate agreement, 0.61 to 0.80 represented substantial agreement, and greater than 0.80 represented almost perfect agreement [10].

\section{Data Extraction}

Following screening, the two reviewers (MA \& AA) independently used a standardized data extraction form (found in Supporting Information S1). Information on the patient demographics for each article was extracted, including age, number of enrolled patients, gender ratio, asthma severity, and forced expiratory volume (FEV1) baseline measures. Moreover, the treatment regimen, consisting of dose and type of ICS used during the intervention, as well as the duration of treatment, was also identified for each article. Finally, information regarding the sputum induction procedure and sputum eosinophil measures was collected for each article. Disagreement between the two reviewers was resolved by consensus and consultation of a neutral third individual (MD \& JJR) used in instances where both reviewers could not agree.

\section{Assessment of the risk of bias}

Two reviewers (MA \& AA) independently assessed the risk of bias for each included study using the Cochrane Risk of Bias Tool [11]. Disagreement between the two reviewers was resolved by consensus. Each article was evaluated based on risk of bias for the following criteria: sequence generation, allocation concealment, blinding, incomplete outcome data, selective outcome reporting, and other sources of bias. For a study that reported a low risk of bias for all the criteria, it was unlikely that any plausible bias would seriously alter the results. For a study that reported an unclear risk of bias for one or more of the criteria, any plausible bias would raise doubt about the results. For a study that reported a high risk of bias for one or more of the criteria, any plausible bias would seriously weaken confidence in the results [11].

\section{RESULTS}

The initial search conducted in MEDLINE, EMBASE, and ISI using the comprehensive search strategy produced 447 results. Following the removal of 90 duplicate articles, title and abstract screening was conducted for 357 unique citations. After this first stage of screening, 66 articles met the criteria for the next stage (estimated kappa $=0.84$ ). Full-text screening was then conducted on these remaining articles; 29 of the 66 articles were excluded [12-40]. Primary reasons for exclusion included: lack of randomization, combination of ICS with other treatments, the use of allergen challenge, and a lack of set treatment dose of patient cohorts. Two of the 29 articles were excluded because they were written in Chinese [13] and Japanese [33]. In total, 37 articles met the inclusion criteria and went on to data extraction (estimated kappa $=0.85$ ) [41-77]. Figure 1 illustrates the PRISMA flow diagram summary of the review process. No unpublished studies met the criteria for inclusion in this review. The 37 articles were assessed for risk of bias [11], and six articles had a low risk of bias $[43,57,70,75-77], 17$ had an unclear risk of bias $[42,46,47,52,53,55,56,58,61,63-66,69,71-73]$, and 14 had a high risk of bias $[41,44,45,48-51,54,59,60,62,67,68,74]$. Detailed results for the risk of bias assessment of each article can be found in Supporting Information S1.

The included articles utilized the following types of ICS: budesonide, fluticasone propionate (FP), ciclesonide, beclomethasone dipropionate (BD), and mometasone. Table 1 provides a summary of the number of reviewed studies according to ICS treatment. The results for each of the ICS are provided in Tables 2-6; the author, sample size, age, asthma severity, predicted FEV1\% predicted at baseline, dose, duration, eosinophil count, and risk of bias is reported for each of the included studies. Table 2 provides a summary of budesonide studies [42-56], in which nine of 16 intervention groups demonstrated a statistically significant $(p<0.05)$ decrease in sputum eosinophil count $[43-46,48,50,51,53,54]$. Table 3 provides a summary of the FP studies [41,57-67], in which five of 14 intervention groups dem-

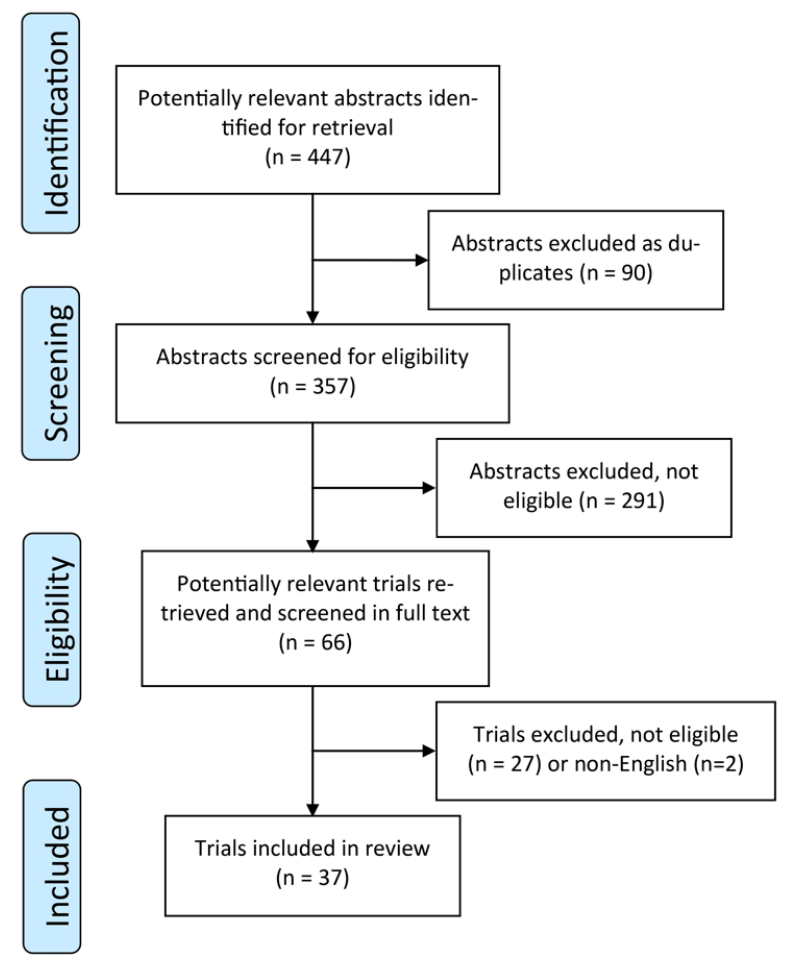

Figure 1: Preferred Reporting Items for Systematic Reviews and Meta-Analyses (PRISMA) flow diagram showing stages of systematic review of randomized controlled trials for effectiveness of inhaled corticosteroids on sputum eosinophilia among asthmatic patients. 
Table 1: Summary of RCTs based on treatment

\begin{tabular}{|c|c|}
\hline ICS Treatment & Number of RCTs Reviewed \\
\hline Budesonide $^{42-56}$ & 15 \\
\hline FP $^{57-67}$ & 11 \\
\hline Ciclesonide $^{68-72}$ & 5 \\
\hline BD $^{73-75}$ & 3 \\
\hline Mometasone $^{76,77}$ & 2 \\
\hline FP or Ciclesonide $^{41}$ & 1 \\
\hline
\end{tabular}

* Statistically Significant $(p<0.05)$; NS - Not significant;

ICS - Inhaled corticosteroids; RCT - Randomized controlled trial;

FP - Fluticasone propionate; BD - Beclomethasone dipropionate

onstrated a statistically significant $(p<0.05)$ decrease in sputum eosinophil count [58,62-65]. Table 4 provides a summary of ciclesonide studies [41,68-72], in which four of nine intervention groups demonstrated a statistically significant $(p<0.05)$ decrease in sputum eosinophil count. Table 5 provides a summary of BD studies [73-75], in which three of five intervention groups demonstrated a statistically significant $(p<0.05)$ decrease in sputum eosinophil count. Table 6 provides a summary of mometasone studies $[76,77]$, in which one of two intervention groups demonstrated a statistically significant $(p<0.05)$ decrease in sputum eosinophil count [76].

\section{DISCUSSION}

This review is unique in that it is the first to investigate RCTs on asthmatic patients receiving ICS and reporting sputum eosinophilia outcomes. It reports on the status of efficacy of more recent ICS treatments in the last 10 years. In evaluating the significance of changes in sputum eosinophil counts, it is important to account for the baseline sputum eosinophil measures for all of these patient groups. There was considerable variation in the reductions in sputum eosinophilia within the same treatments and even under the same doses; this may be attributable to differences in baseline patient sputum eosinophils.

Eosinophilic asthma is characterized by a sputum eosinophil proportion greater than $2 \%$ [78], and we do not expect that ICS treatments would be effective in significantly reducing sputum eosinophilia in asthmatic patients that fall below this threshold, as this would be considered a non-pathological level. Since the baseline eosinophil count for each study is a mean of the treatment group, we cannot say that any one set of patients consists completely of patients with eosinophilic asthma, or does not contain any of them. However, the mean baseline value can be used as an indicator of what proportion of eosinophilic asthmatic patients we can expect in a treatment group. Ideally, we would see a significant reduction in sputum eosinophila in patient groups with higher baseline measures for an effective ICS treatment. On the other hand, we anticipate that the baseline values of noneosinophlic asthmatic patients remain stable for the same treatment. It should be noted that even if the mean baseline sputum eosinophil values falls just above the $2 \%$ threshold, it may still contain a significant proportion of non-eosinophilic asthmatic patients. This may skew the results leading to a non-significant change in sputum eosinophilia.

Of the 46 total intervention groups included in this review, 22 demonstrated statistically significant decreases in sputum eosinophils. Within these 22 treatment groups, 20 presented a mean baseline measure greater than the $2 \%$ eosinophilic asthma cutoff, one presented a value below the $2 \%$ cut-off, and two groups did not report the mean baseline eosinophils. In contrast, the 24 groups with a non-significant change in sputum eosinophils showed 16 of them to be above the $2 \%$ cut-off for eosinophilic asthma, six of them to be below the cut-off, and two without reported mean baseline eosinophils. However, six of the 16 groups above the $2 \%$ cut-off were still fairly close to this threshold, reporting sputum eosinophil values below 3\%. These results may indicate greater efficacy of ICS reduction of sputum eosinophils more specifically in the eosinophilic subset of asthma. Moreover, the treatment durations for four intervention groups in studies Gauvreau et al. [69] and Erin et al. [70] ranged from five to seven days each; these studies had the shortest treatment duration of all included RCTs in this review. This shorter treatment period may have contributed to the non-significant change in sputum eosinophils. Finally, the results of Menezes et al. [49] should be interpreted with caution, as there was a severe imbalance in the loss to follow-up between the two treatment groups; eight of 19 patients were lost in one group, while only one of 13 patients were lost in the other group.

\section{Limitations}

There are several limitations to this review of the literature. First, due to heterogeneity in the doses, durations, and baseline sputum eosinophil measures, the resulting changes in sputum eosinophilia were not pooled in meta-analysis for the individual ICS treatments. Furthermore, another minor issue deterring the authors from pooling the results was a lack of reporting quantitative changes in sputum eosinophilia. Also, study authors were not contacted for missing data. Only English articles were included, although only 2 non-English articles were identified during screening and would therefore be unlikely to significantly affect our conclusions.

Another limitation of this review is the method by which the efficacy of the drug was evaluated. For the purposes of this paper, an RCT that reported a statistically significant decrease in sputum eosinophilia indicated that the ICS in question was effective. However, this statistical significance does not necessarily equate to clinical significance. That is to say, a small change in sputum eosinophilia may result in a statistically significant difference, but it may not be sufficiently beneficial to the patient to warrant a change in clinical practice. Ideally, a clinically significant threshold of change from baseline eosinophil counts may be identified 
that consistently translates into measurably improved clinical outcomes, such as the FEV1, for patients with asthma, leading to improved disease management.

In addition, some ICS treatments were missed because RCTs published only in the last 10 years were investigated [7]. For example, Condemi et al. [79] and Lazarus et al. [80] both tested triamcinolone, an alternative ICS that was not evaluated in this review, since it fell outside the 10-year period. However, considering there have not been recent studies published on triamcinolone, and other ICS not included in the review, it can be inferred that they are no longer considered first-line ICS treatments due to more effective medications being available. Given that the goal of this review was to evaluate the most recent ICS treatments for patients with asthma, studies such as the ones on triamcinolone fall outside the scope of this paper. In future studies, it would be beneficial to also evaluate ICS in combination therapies as this is often the case in the clinical setting and thus would improve external validity. The risk of bias in the included RCTs for this review also proved to be a potential limitation. Of the 37 studies included, only six had a low risk of bias, with the remaining studies either having an unclear or high risk of bias. Consequently, the results of these studies should be interpreted with caution.

Finally, given that this review investigated changes in sputum eosinophilia as the primary outcome, we were limited on the population of asthmatic patients that we could investigate. As previously discussed, in patients with non-eosinophilic asthma, we would not expect a significant reduction in sputum eosinophilia. As such, a potential option for this review would have been to focus strictly on eosinophilic asthmatics. However, most studies only reported mean baseline sputum eosinophil measures, and did not report on whether all patients were greater than the $2.0 \%$ threshold. Thus, we used the mean baseline values as an indicator for the individual patients, but were aware that there may have been significant variation within the patient groups.

\section{CONCLUSION}

This study discussed the effects of ICS on sputum eosinophils in asthma patients; however, the clinical relevance is uncertain. There is insufficient evidence to suggest the superiority of one ICS treatment over another. Further research needs to be conducted evaluating the relative impact of ICS products upon eosinophil counts, as well as in clarifying what quantitative level of change in baseline eosinophil counts is required to observe a change in symptom improvement and disease control. Ideally, the further research in this field would include more high quality studies with low risk of bias in concordance with the Cochrane Risk of Bias Tool [11], and a meta-analysis of all trials evaluating ICS treatments.

\section{REFERENCES}

1. Boulet LP, Becker A, Berube D, Beveridge R, Ernst P. Canadian asthma consensus report 1999. Canadian Asthma Consensus Group. 1999;161(11 Suppl):S1-61.

2. Djukanovic R, Roche WR, Wilson JW, et al. Mucosal inflammation in asthma: state of the art. Am Rev Respir Dis. 1990;142:434-57.

3. Barnes PJ. Inhaled corticosteroids: new developments relevant to updating of asthma management guidelines. Respir Med. 1996;90:379-84.

4. Barnes PJ. Anti-inflammatory actions of glucocorticoids: molecular mechanisms. Clin Sci. 1998;94:557-72.

5. Djukanovic R, Sterk PJ, Fahy JV, Hargreave FE. Standardized methodology of sputum induction and processing. Eur Respir J. 2002;20(Suppl. 37):S1-55.

6. Lemiere CM, FitzGerald M. Canadian Thoracic Society 2012 guideline update: diagnosis and management of asthma in preschoolers, children and adults. Can Respir J. 2012;19(2):127-64.

7. Rank MA, Hagan JB, Park MA, et al. The risk of asthma exacerbation after stopping low-dose inhaled corticosteroids: A systematic review and meta-analysis of randomized controlled trials. J Allergy Clin Immunol. 2013;131(3):724-9.

8. Gan WQ, Man SP, Sin DD. Effects of inhaled corticosteroids on sputum cell counts in stable chronic obstructive pulmonary disease: a systematic review and a meta-analysis. BMC pulmonary medicine. 2005;5(1):3.

9. Moher D, Liberati A, Tetzlaff J, Altman DG. Preferred reporting items for systematic reviews and meta-analyses: the PRISMA statement. Ann Intern Med. 2009;151(4):264-9.

10. Landis JR, Koch GG. The measurement of observer agreement for categorical data. Biometrics. 1977;33(1):159-75.

11. The Cochrane Collaboration. Cochrane Handbook for Systematic Reviews of Interventions (Version 5.0.2). Oxford,UK: Cochrane Collaboration; 2009.

12. Boushey $\mathrm{H}$, Sorkness $\mathrm{C}$, King $\mathrm{T}$. Intermittent therapy effective for mild persistent asthma. J Fam Pract. 2005;54(7):577-84.

13. Cao WL, Sun YC, Yao WZ. A study on a therapeutic protocol to improve the control of persistent asthma by monitoring sputum eosinophil counts. Zhonghua Jie He He Hu Xi Za Zhi. 2007;30(5):334-8.

14. Chlumský J, Striz I, Terl M, Vondracek J. Strategy aimed at reduction of sputum eosinophils decreases exacerbation rate in patients with asthma. J Int Med Res. 2006;34(2):129-39.

15. Cowan DC, Cowan JO, Palmay R, Williamson A, Taylor DR. Simvastatin in the treatment of asthma: lack of steroid-sparing effect. Thorax. 2010;65(10):891-6

16. Dahl R, Nielsen L, Kips J, et al. (2005) Intranasal and inhaled fluticasone propionate for pollen-induced rhinitis and asthma. Allergy. 2005;60(7):875-81.

17. Deykin A, Lazarus SC, Fahy JV, Wechsler ME, Boushey HA, Chinchilli VM, et al. Sputum eosinophil counts predict asthma control after discontinuation of inhaled corticosteroids. J Allergy Clin Immunol. 2005;115(4):720-7.

18. Duong M, Amin R, Baatjes AJ, Kritzinger F, Qi Y, Meghji Z, et al. The effect of montelukast, budesonide alone, and in combination on exercise-induced bronchoconstriction. J Allergy Clin Immunol. 2012;130(2):535-9.

19. Duong M, Gauvreau G, Watson R, et al. The effects of inhaled budesonide and formoterol in combination and alone when given directly after allergen challenge. J Allergy Clin Immunol. 2007;119(2):322-7.

20. Fagan HB, Harwood M. Use of sputum eosinophil count decreases asthma exacerbations. J Fam Pract. 2003;52(5):353-4.

21. Heijink IH, Kauffman HF, Vellenga E, Veltman-Starkenburg CA, Postma DS, de Monchy JG. Effect of ciclesonide treatment on allergen-induced changes in T cell regulation in asthma. Int Arch Allergy Immunol. 2007;145(2):111-21.

22. Horiguchi T, Hayashi N, Ohira D, et al. Usefulness of HFA-BDP for adult patients with bronchial asthma: randomized crossover study with fluticasone. J Asthma. 2006;43(7):509-12.

23. Horiguchi T, Tachikawa S, Kondo R, et al. Comparative evaluation of the leukotriene receptor antagonist pranlukast versus the steroid inhalant fluticasone in the therapy of aged patients with mild bronchial asthma. Arzneimittelforschung. 2007;57(02):87-91.

24. Hoshino M, Ohtawa J. Effects of adding omalizumab, an anti-immunoglobulin $E$ antibody, on airway wall thickening in asthma. Respiration. 2012;83(6):520-8.

25. Janson SL, Fahy JV, Covington JK, Paul SM, Gold WM, Boushey HA. Effects of individual self-management education on clinical, biological, and adherence outcomes in asthma. Am J Med. 2003;115(8):620-6. 
26. Jayaram L, Pizzichini $M$, Cook $R$, et al. Determining asthma treatment by monitoring sputum cell counts: effect on exacerbations. Eur Resp J. 2006;27(3):483-94.

27. Kawayama T, O'Byrne $P$, Watson $R$, et al. Effects of inhaled ciclesonide on circulating T-helper type 1/T-helper type 2 cells in atopic asthmatics after allergen challenge. Clin Exp Allergy. 2006;36(11):1417-24.

28. Koopmans JG, Lutter R, Jansen HM, van der Zee, Jaring S. Adding salmeterol to an inhaled corticosteroid reduces allergen-induced serum IL-5 and peripheral blood eosinophils. J Allergy Clin Immunol. 2005;116(5):1007-13.

29. Lemière C, Tremblay C, FitzGerald M, et al. Effects of a short course of inhaled corticosteroids in noneosinophilic asthmatic subjects. Can Respir J. 2011;18(5):278-82.

30. Luijk B, van den Berge $M$, Kerstjens $H$, et al. Effect of an inhaled adenosine $\mathrm{A} 2 \mathrm{~A}$ agonist on the allergen-induced late asthmatic response. Allergy. 2008;63(1):75-80.

31. Ohbayashi H, Adachi M. Hydrofluoroalkane-beclomethasone dipropionate effectively improves airway eosinophilic inflammation including the distal airways of patients with mild to moderate persistent asthma as compared with fluticasone propionate in a randomized open double-cross study. Allergol Int. 2008;57(3):231-9.

32. Ohbayashi H, Shibata N, Hirose T, Adachi M. Additional effects of pranlukast in salmeterol/fluticasone combination therapy for the asthmatic distal airway in a randomized crossover study. Pulm Pharmacol Ther. 2009;22(6):5749.

33. Ohbayashi $\mathrm{H}$, Adachi $\mathrm{M}$, Ichinose $\mathrm{M}$, et al. A multicenter, open-label, randomized comparison of suppressive effects on asthmatic inflammation of lower airways and improved effects on health-related QOL between HFABDP and fluticasone propionate. Arerugi. 2007;56(6):577-86.

34. Palmqvist $M$, Bruce $C$, Sjöstrand $M$, Arvidsson $P$, Lötvall J. Differential effects of fluticasone and montelukast on allergen-induced asthma. Allergy. 2005;60(1):65-70.

35. Pavord ID, Jeffery PK, Qiu Y, et al. Airway inflammation in patients with asthma with high-fixed or low-fixed plus as-needed budesonide/formoterol. J Allergy Clin Immunol. 2009;123(5):1083-9.

36. Pavord I, Woodcock A, Parker D, Rice L, SOLTA Study Group. Salmeterol plus fluticasone propionate versus fluticasone propionate plus montelukast: a randomised controlled trial investigating the effects on airway inflammation in asthma. Respir Res. 2007;8(1):67.

37. Peroni D, Bodini A, Miraglia Del Giudice M, et al. Effect of budesonide and montelukast in asthmatic children exposed to relevant allergens. Allergy. 2005;60(2):206-10.

38. Subbarao P, Dorman SC, Rerecich T, Watson RM, Gauvreau GM, O'Byrne $\mathrm{PM}$. Protection by budesonide and fluticasone on allergen-induced airway responses after discontinuation of therapy. J Allergy Clin Immunol. 2005;115(4):745-50.

39. Ten Brinke A, Zwinderman AH, Sterk PJ, Rabe KF, Bel EH. "Refractory" eosinophilic airway inflammation in severe asthma: effect of parenteral corticosteroids. Am J Respir Crit Care Med. 2004;170(6):601-5.

40. Tien Nguyen L, Lim S, Oates T, Chung KF. Increase in airway neutrophils after oral but not inhaled corticosteroid therapy in mild asthma. Respir Med. 2005;99(2):200-7.

41. Hoshino M. Comparison of effectiveness in ciclesonide and fluticasone propionate on small airway function in mild asthma. Allergol Int. 2010;59(1):5966.

42. Green R, Brightling C, McKenna S, et al. Comparison of asthma treatment given in addition to inhaled corticosteroids on airway inflammation and responsiveness. Eur Respir J. 2006;27(6):1144-51.

43. Kelly MM, O'Connor TM, Leigh R, et al. Effects of budesonide and formoterol on allergen-induced airway responses, inflammation, and airway remodeling in asthma. J Allergy Clin Immunol. 2010;125(2):349-56.

44. Hoshino M, Ohtawa J. Effects of budesonide/formoterol combination therapy versus budesonide alone on airway dimensions in asthma. Respirology. 2012;17(4):639-46.

45. Basyigit I, Yildiz F, Kacar Ozkara S, Boyaci H, Ilgazli A, Ozkarakas O. Effects of different anti-asthmatic agents on induced sputum and eosinophil cationic protein in mild asthmatics. Respirology. 2004;9(4):514-20.

46. Hauber H, Taha R, Bergeron C, Migounov V, Hamid Q, Olivenstein R. Effects of hydrofluoroalkane and dry powder-formulated corticosteroids on sputum inflammatory markers in asthmatic patients. Can Respir J. 2006;13(2):73.

47. Barnes $N$, Laviolette $M$, Allen $D$, et al. Effects of montelukast compared to double dose budesonide on airway inflammation and asthma control.
Respir Med. 2007;101(8):1652-8.

48. Rytilä P, Pelkonen A, Metso T, Nikander K, Haahtela T, Turpeinen M. Induced sputum in children with newly diagnosed mild asthma: the effect of 6 months of treatment with budesonide or disodium cromoglycate. Allergy. 2004;59(8):839-44.

49. Menezes MB, Teixeira AL, Vianna EO. Inflammatory and functional effects of increasing asthma treatment with formoterol or double dose budesonide. Respir Med. 2008;102(10):1385-91.

50. Perng D, Huang H, Lee Y, Perng R. Leukotriene Modifier vs Inhaled Corticosteroid in Mild-to-Moderate Asthma: Clinical and Anti-inflammatory Effects. Chest. 2004;125(5):1693-9.

51. Echevarria EMU, Maldonado CA, Echevaria AMU, Aoki A. Neutrophil predominance in induced sputum from asthmatic patients. Therapeutic implications and role of clara cell 16-KD protein. Medicana (B Aires). 2011;71(4):343-9.

52. Strauch $E$, Moske $\mathrm{O}$, Thoma $\mathrm{S}$. A randomized controlled trial on the effect of montelukast on sputum eosinophil cationic protein in children with corticosteroid-dependent asthma. Pediatr Res. 2003;54(2):198-203.

53. Maneechotesuwan K, Ekjiratrakul W, Kasetsinsombat K, Wongkajornsilp A, Barnes PJ. Statins enhance the anti-inflammatory effects of inhaled corticosteroids in asthmatic patients through increased induction of indoleamine 2, 3-dioxygenase. J Allergy Clin Immunol. 2010;126(4):754-62.

54. Van Dalen CJ, Aldridge RE, Chan T, et al. Bromotyrosines in sputum proteins and treatment effects of terbutaline and budesonide in asthma. Ann Allergy Asthma Immunol. 2009;103(4):348-53.

55. Boulet L, Lemière C, Gauvreau G, et al. Safety, pharmacodynamics and pharmacokinetics of TPI 1020 in smokers with asthma. Respir Med. 2009;103(8):1159-66.

56. Maneechotesuwan K, Essilfie-Quaye S, Kharitonov SA, Adcock IM, Barnes PJ. Loss of control of asthma following inhaled corticosteroid withdrawal is associated with increased sputum interleukin-8 and neutrophils. Chest. 2007;132(1):98-105.

57. Belda J, Margarit G, Martínez C, et al. Anti-inflammatory effects of highdose inhaled fluticasone versus oral prednisone in asthma exacerbations. Eur Respir J. 2007;30(6):1143-9.

58. Kawayama T, Kinoshita T, Imaoka H, Gauvreau GM, O'Byrne PM, Aizawa H. Effects of inhaled fluticasone propionate on CTLA-4-positive CD4 CD25 cells in induced sputum in mild asthmatics. Respirology. 2008;13(7):1000-7.

59. Hoshino M, Handa $\mathrm{H}$, Miyazawa T. Effects of salmeterol and fluticasone propionate combination versus fluticasone propionate on airway function and eosinophilic inflammation in mild asthma. Allergol Int. 2009;58:357-63.

60. Hozawa S, Haruta Y, Terada M, Yamakido M. Effects of the addition of Beta 2-agonist tulobuterol patches to inhaled corticosteroid in patients with asthma. Allergol Int. 2009;58:509-18.

61. Giannini D, Di Franco A, Tonelli $M$, et al. Fifty $\mu \mathrm{g}$ bid of inhaled fluticasone propionate (FP) are effective in stable asthmatics previously treated with a higher dose of FP. Respir Med. 2003;97(5):463-7.

62. Kanazawa H, Nomura S, Asai K. Roles of angiopoietin-1 and angiopoietin-2 on airway microvascular permeability in asthmatic patients. Chest. 2007;131(4):1035-41.

63. Di Franco A, Bacci E, Laura Bartoli M, et al. Inhaled fluticasone propionate is effective as well as oral prednisone in reducing sputum eosinophilia during exacerbations of asthma which do not require hospitalization. Pulm Pharmacol Ther. 2006;19(5):353-60.

64. Koopmans JG, Lutter R, Jansen HM, van der Zee, Jaring S. Adding salmeterol to an inhaled corticosteroid: long term effects on bronchial inflammation in asthma. Thorax. 2006;61(4):306-13.

65. Jayaram L, Pizzichini E, Lemiere C, et al. Steroid naive eosinophilic asthma: anti-inflammatory effects of fluticasone and montelukast. Thorax. 2005;60(2):100-5.

66. Foresi A, Mastropasqua B, Chetta A, et al. Step-down compared to fixeddose treatment with inhaled fluticasone propionate in asthma. Chest. 2005;127(1):117-24.

67. Bacci E, Latorre M, Cianchetti S, et al. Transient sputum eosinophilia may occur over time in non-eosinophilic asthma and this is not prevented by salmeterol. Respirology. 2012;17(8):1199-206.

68. Wilson A, Duong M, Pratt B, Dolovich M, O'Byrne P. Anti-inflammatory effects of once daily low dose inhaled ciclesonide in mild to moderate asthmatic patients. Allergy. 2006;61(5):537-42.

69. Gauvreau GM, Boulet LP, Postma DS, et al. Effect of low-dose ciclesonide on allergen-induced responses in subjects with mild allergic asthma. J Allergy 
Clin Immunol. 2005;116(2):285-91.

70. Erin EM, Zacharasiewicz AS, Nicholson GC, et al. Rapid Effect of Inhaled Ciclesonide in AsthmaA Randomized, Placebo-Controlled Study. Chest. 2008;134(4):740-5.

71. van den Berge $M$, Arshad $S$, Ind $P$, et al. Similar efficacy of ciclesonide versus prednisolone to treat asthma worsening after steroid tapering. Respir Med. 2009;103(8):1216-23.

72. Duong $M$, Subbarao $P$, Adelroth $E$, et al. Sputum eosinophils and the response of exercise-induced bronchoconstriction to corticosteroid in asthma. Chest. 2008;133(2):404-11.

73. Negro RD, Micheletto C, Tognella S, Turco P, Rossetti A, Cantini L. Assessment of inhaled BDP-dose dependency of exhaled nitric oxide and local and serum eosinophilic markers in steroids-naive nonatopic asthmatics. Allergy. 2003;58(10):1018-22.

74. Wang $\mathrm{Y}$, Wang $\mathrm{C}$, Lin $\mathrm{K}$, et al. Comparison of inhaled corticosteroid combined with theophylline and double-dose inhaled corticosteroid in moderate to severe asthma. Respirology. 2005;10(2):189-95.
75. Lazarus SC, Chinchilli VM, Rollings NJ, et al. Smoking affects response to inhaled corticosteroids or leukotriene receptor antagonists in asthma. Am J Respir Crit Care Med. 2007;175(8):783-90.

76. Berry M, Morgan A, Shaw DE, et al. Pathological features and inhaled corticosteroid response of eosinophilic and non-eosinophilic asthma. Thorax. 2007;62(12):1043-9.

77. Nelson HS, Gallegos CM, Silveira LJ, Newell JD, Gelfand EW. Effect of the inhaled corticosteroid mometasone on small airway patency in patients with asthma. Allerg Asthma Proc. 2009;30(3):284-92.

78. Davies AR, Hancox RJ. Induced sputum in asthma: diagnostic and therapeutic implications. Curr Opin Pulm Med. 2013;19:60-5.

79. Condemi JJ, Chervinsky P, Goldstein MF, et al. Fluticasone propionate powder administered through Diskhaler versus triamcinolone acetonide aerosol administered through metered-dose inhaler in patients with persistent asthma. J Allergy Clin Immunol. 1997;100:467-74.

80. Lazarus SC, Boushey HA, Fahy JV, et al. Long-acting b2-agonist monotherapy vs continued therapy with inhaled corticosteroids in patients with persistent asthma: a randomized controlled trial. JAMA. $2001 ; 285: 2583-93$

Table 2: Summary of Budesonide ICS RCTs

\begin{tabular}{|c|c|c|c|c|c|c|c|c|c|}
\hline Author (year) & $\begin{array}{l}\text { Intervention } \\
\text { group sample } \\
\text { size }\end{array}$ & $\begin{array}{c}\text { Mean } \\
\text { Age }\end{array}$ & $\begin{array}{l}\text { Asthma } \\
\text { Severity }\end{array}$ & $\begin{array}{c}\mathrm{FEV}_{1} \% \\
\text { predicted } \\
\text { at baseline }\end{array}$ & Dose $(\mu g)$ & Duration & $\begin{array}{c}\text { Mean } \\
\text { baseline } \\
\text { eosino- } \\
\text { phil count }\end{array}$ & $\begin{array}{c}\text { Mean } \\
\text { change in } \\
\text { eosinophil } \\
\text { count }\end{array}$ & $\begin{array}{c}\text { Risk of } \\
\text { bias }\end{array}$ \\
\hline \multirow{2}{*}{ Green et al. (2006) } & \multirow{2}{*}{49} & \multirow{2}{*}{42} & \multirow{2}{*}{ Persistent } & \multirow{2}{*}{74.8} & 200 & \multirow{2}{*}{4 weeks } & $2.8 \%$ & $-0.3 \%$ & \multirow{2}{*}{ Unclear } \\
\hline & & & & & 800 & & $2.7 \%$ & $-1.1 \%$ & \\
\hline Kelly et al. $(2010)^{43}$ & 14 & 29 & Mild, stable & 82.2 & 400 & 11 days & $2.5 \%$ & $-1.5 \% *$ & Low \\
\hline $\begin{array}{l}\text { Hoshino et al. } \\
\qquad(2012)^{44}\end{array}$ & 13 & 29 & $\begin{array}{c}\text { Mild to } \\
\text { moderate, } \\
\text { persistent }\end{array}$ & 77.9 & 400 & 24 weeks & $5.2 \%$ & $-0.6 \%{ }^{*}$ & High \\
\hline Basyigit et al. $(2004)^{45}$ & 10 & 42 & $\mathrm{~N} / \mathrm{A}$ & 89.5 & 400 & 2 weeks & $18.0 \%$ & $-9.0 \% *$ & High \\
\hline Hauber et al. $(2006)^{46}$ & 9 & 35 & Mild & 90.2 & 800 & 4 weeks & $9.7 \%$ & $-2.0 \% *$ & Unclear \\
\hline Barnes et al. $(2007)^{47}$ & 38 & 45 & Persistent & 73.6 & 1600 & 4 weeks & $0.5 \%$ & $+0.2 \%$ & Unclear \\
\hline Rytila et al. $(2004)^{48}$ & 39 & 7 & $\begin{array}{l}\text { Mild, persis- } \\
\text { tent }\end{array}$ & 90.9 & $\begin{array}{c}800 \\
(4 \text { weeks); } \\
400 \\
\text { (20 weeks) }\end{array}$ & 24 weeks & $6.0 \%$ & $-4.0 \% *$ & High \\
\hline $\begin{array}{c}\text { Menezes et al. } \\
(2008)^{49}\end{array}$ & 10 & 43 & $\begin{array}{l}\text { Moderate to } \\
\text { severe }\end{array}$ & 81.2 & 800 & 9 weeks & $8.2 \%$ & $-5.3 \%$ & High \\
\hline Perng et al. $(2004)^{50}$ & 21 & 45 & $\mathrm{~N} / \mathrm{A}$ & 83.0 & 1200 & 6 weeks & $16.8 \%$ & $-10.2 \%$ * & Hight \\
\hline $\begin{array}{l}\text { Echevarria et al. } \\
\qquad(2011)^{51}\end{array}$ & 33 & 26 & $\begin{array}{l}\text { Mild to } \\
\text { severe }\end{array}$ & 89.5 & 800 & 6 weeks & $28.0 \%$ & Decrease $^{*}$ & High \\
\hline Strauch et al. $(2003)^{52}$ & 25 & 10 & $\mathrm{~N} / \mathrm{A}$ & 97.0 & $400-800$ & 4 weeks & $1.6 \%$ & $-0.6 \%$ & Unclear \\
\hline $\begin{array}{c}\text { Maneechotes-uwan } \\
\text { et al. }(2010)^{53}\end{array}$ & 25 & 52 & Stable & 85.5 & 200 & 8 weeks & $12.5 \%$ & $-6.3 \% *$ & Unclear \\
\hline $\begin{array}{l}\text { van Dalen et al. } \\
(2009)^{54}\end{array}$ & 34 & 39 & $\begin{array}{l}\text { Mild to mod- } \\
\text { erate }\end{array}$ & 89.5 & 400 & 6 weeks & $\mathrm{N} / \mathrm{A}$ & Decrease $^{*}$ & Unclear \\
\hline Boulet et al. (2009) & 14 & 35 & Mild & 87.4 & $\begin{array}{c}800 \\
(2 \text { weeks }) ; \\
1600 \\
(1 \text { week })\end{array}$ & 3 weeks & $2.4 \%$ & $-1.4 \%$ & Unclear \\
\hline $\begin{array}{c}\text { Maneechotes-uwan } \\
\text { et al. }(2007)^{56}\end{array}$ & 12 & 38 & $\begin{array}{l}\text { Moderate, } \\
\text { persistent }\end{array}$ & 72.3 & 800 & 10 weeks & $4.8 \%$ & $-4.5 \%$ & Unclear \\
\hline
\end{tabular}

* Statistically Significant ( $\mathrm{p}<\mathrm{0.05}$ ); NS - Not significant; ICS - Inhaled corticosteroids; RCT - Randomized controlled trial; FEV1 - Forced expiratory volume in 1 second; $\mu \mathrm{g}$ - Microgram 
Table 3: Summary of FP ICS RCTs

\begin{tabular}{|c|c|c|c|c|c|c|c|c|c|}
\hline Author (year) & $\begin{array}{c}\text { Intervention } \\
\text { group sample } \\
\text { size }\end{array}$ & $\begin{array}{c}\text { Mean } \\
\text { Age }\end{array}$ & $\begin{array}{l}\text { Asthma } \\
\text { Severity }\end{array}$ & $\begin{array}{c}\mathrm{FEV}_{1} \% \\
\text { predicted } \\
\text { at baseline }\end{array}$ & Dose $(\mu \mathrm{g})$ & Duration & $\begin{array}{c}\text { Mean } \\
\text { baseline } \\
\text { eosino- } \\
\text { phil count }\end{array}$ & $\begin{array}{c}\text { Mean } \\
\text { change in } \\
\text { eosinophil } \\
\text { count }\end{array}$ & $\begin{array}{c}\text { Risk of } \\
\text { bias }\end{array}$ \\
\hline Belda et al. $(2007)^{57}$ & 19 & 39 & Moderate & 69.0 & 4000 & 24 hours & $13.0 \%$ & $-6.6 \%$ & Low \\
\hline $\begin{array}{l}\text { Kawayama et al. } \\
\quad(2008)^{58}\end{array}$ & 11 & 27 & Mild, stable & 97.7 & 400 & 2 weeks & $12.2 \%$ & $-4.8 \%^{*}$ & Unclear \\
\hline $\begin{array}{l}\text { Hoshino et al. } \\
(2009)^{59}\end{array}$ & 14 & 43 & $\begin{array}{c}\text { Mild, } \\
\text { persistent }\end{array}$ & 87.0 & 200 & 8 weeks & $5.1 \%$ & $-0.7 \%$ & High \\
\hline $\begin{array}{l}\text { Hozawa et al. } \\
\qquad(2009)^{60}\end{array}$ & 12 & 50 & Stable & 84.4 & $200 / 400 / 800$ & 4 weeks & $11.4 \%$ & $+0.7 \%$ & High \\
\hline \multirow{2}{*}{$\begin{array}{c}\text { Giannini et al. } \\
(2003)^{61}\end{array}$} & \multirow{2}{*}{9} & \multirow{2}{*}{$\begin{array}{l}35 \\
40 \\
\end{array}$} & \multirow{2}{*}{ Stable } & 100.5 & 250 & \multirow{2}{*}{12 weeks } & $1.9 \%$ & $-0.3 \%$ & \multirow{2}{*}{ Unclear } \\
\hline & & & & 104.5 & 100 & & $3.3 \%$ & $-2.0 \%$ & \\
\hline $\begin{array}{c}\text { Kanazawa et al. } \\
(2007)^{62}\end{array}$ & 15 & 36 & N/A & 90.5 & 400 & 12 weeks & $12.1 \%$ & $-11.3 \%^{*}$ & High \\
\hline $\begin{array}{l}\text { Di Franco et al. } \\
\qquad(2006)^{63}\end{array}$ & 18 & 43 & N/A & 90.1 & 1000 & 2 weeks & $38.0 \%$ & $-35.0 \%^{*}$ & Unclear \\
\hline $\begin{array}{l}\text { Koopmans et al. } \\
\qquad(2006)^{64}\end{array}$ & 27 & 32 & $\begin{array}{c}\text { Moderate to } \\
\text { moderate, } \\
\text { persistent }\end{array}$ & 89.9 & 500 & 4 weeks & $3.2 \%$ & $-2.4 \%^{*}$ & Unclear \\
\hline $\begin{array}{l}\text { Jayaram et al. } \\
(2005)^{65}\end{array}$ & 18 & 35 & Persistent & 72.0 & 250 & 8 weeks & $11.9 \%$ & $-10.2 \%^{*}$ & Unclear \\
\hline \multirow{2}{*}{ Foresi et al. $(2005)^{66}$} & 18 & 38 & \multirow{2}{*}{ N/A } & 83.8 & 1000 & \multirow{2}{*}{6 weeks } & $16.4 \%$ & $-15.4 \%$ & \multirow{2}{*}{ Unclear } \\
\hline & 17 & 34 & & 88.8 & 200 & & $16.7 \%$ & $-13.9 \%$ & \\
\hline Bacci et al. $(2012)^{67}$ & 10 & 42 & $\begin{array}{l}\text { Mild to } \\
\text { moderate }\end{array}$ & 92.6 & 250 & 24 weeks & $<3.0 \%$ & NS & High \\
\hline $\begin{array}{l}\text { Hoshino et al. } \\
\qquad(2010)^{41}\end{array}$ & 16 & 45 & $\begin{array}{l}\text { Mild, } \\
\text { persistent }\end{array}$ & 98.6 & 200 & 8 weeks & $11.8 \%$ & -1.0 & High \\
\hline
\end{tabular}

* Statistically Significant $(\mathrm{p}<\mathbf{0 . 0 5})$; NS - Not significant; ICS - Inhaled corticosteroids; RCT - Randomized controlled trial; FEV1 - Forced expiratory volume in 1 second; $\mu \mathrm{g}$ - Microgram 
Table 4: Summary of Ciclesonide ICS RCTs

\begin{tabular}{|c|c|c|c|c|c|c|c|c|c|}
\hline Author (year) & $\begin{array}{c}\text { Intervention } \\
\text { group sample } \\
\text { size }\end{array}$ & $\begin{array}{c}\text { Mean } \\
\text { Age }\end{array}$ & $\begin{array}{l}\text { Asthma } \\
\text { Severity }\end{array}$ & $\begin{array}{c}\mathrm{FEV}_{1} \% \\
\text { predicted } \\
\text { at baseline }\end{array}$ & Dose $(\mu \mathrm{g})$ & Duration & $\begin{array}{c}\text { Mean } \\
\text { baseline } \\
\text { eosinophil } \\
\text { count }\end{array}$ & $\begin{array}{c}\text { Mean } \\
\text { change in } \\
\text { eosinophil } \\
\text { count }\end{array}$ & $\begin{array}{c}\text { Risk of } \\
\text { bias }\end{array}$ \\
\hline Wilson et al. $(2006)^{68}$ & 8 & 22 & $\begin{array}{l}\text { Mild, } \\
\text { persistent }\end{array}$ & 69.0 & 160 & 4 weeks & $6.0 \%$ & $-1.5 \% *$ & Low \\
\hline \multirow{2}{*}{$\begin{array}{l}\text { Gauvreau et al. } \\
(2005)^{69}\end{array}$} & \multirow{2}{*}{22} & \multirow{2}{*}{33} & \multirow{2}{*}{ Mild } & \multirow{2}{*}{97.7} & 40 & \multirow{2}{*}{5 days } & $9.0 \%$ & $6.3 \%$ & \multirow{2}{*}{ Unclear } \\
\hline & & & & & 80 & & $5.0 \%$ & $1.6 \%$ & \\
\hline \multirow{2}{*}{ Erin et al. $(2008)^{70}$} & \multirow{2}{*}{21} & \multirow{2}{*}{26} & \multirow{2}{*}{ Persstent } & \multirow{2}{*}{87.0} & 320 & \multirow{2}{*}{1 weeks } & $\mathrm{N} / \mathrm{A}$ & NS & \multirow{2}{*}{ Low } \\
\hline & & & & & 1280 & & N/A & NS & \\
\hline $\begin{array}{c}\text { van den Berge et al. } \\
(2009)^{71}\end{array}$ & 67 & 45 & Stable & 84.4 & 1600 & 2 weeks & $0.9 \%$ & $-0.3 \%^{*}$ & Unclear \\
\hline \multirow{2}{*}{ Duong et al. $(2008)^{72}$} & 12 & 35 & \multirow{2}{*}{ N/A } & 100.5 & $40 / 80$ & \multirow{2}{*}{3 weeks } & $2.5 \%$ & $-0.9 \%$ & \multirow{2}{*}{ Unclea } \\
\hline & 13 & 40 & & 104.5 & $160 / 320$ & & $3.3 \%$ & $-2.1 \%^{*}$ & \\
\hline $\begin{array}{l}\text { Hoshino et al. } \\
\qquad(2010)^{41}\end{array}$ & 14 & 36 & $\begin{array}{c}\text { Mild, } \\
\text { persistent }\end{array}$ & 90.5 & 200 & 8 weeks & $12.2 \%$ & $-5.3 \%^{*}$ & High \\
\hline
\end{tabular}

* Statistically Significant $(\mathbf{p}<0.05)$; NS - Not significant; ICS - Inhaled corticosteroids; RCT - Randomized controlled trial; FEV1 - Forced expiratory volume in 1 second; $\mu \mathrm{g}$ - Microgram

Table 5: Summary of BD ICS RCTs

\begin{tabular}{|c|c|c|c|c|c|c|c|c|c|}
\hline Author (year) & $\begin{array}{c}\text { Intervention } \\
\text { group sample } \\
\text { size }\end{array}$ & $\begin{array}{c}\text { Mean } \\
\text { Age }\end{array}$ & $\begin{array}{l}\text { Asthma } \\
\text { Severity }\end{array}$ & $\begin{array}{c}\mathrm{FEV}_{1} \% \\
\text { predicted } \\
\text { at baseline }\end{array}$ & Dose $(\mu \mathrm{g})$ & Duration & $\begin{array}{c}\text { Mean } \\
\text { baseline } \\
\text { eosinophil } \\
\text { count }\end{array}$ & $\begin{array}{c}\text { Mean } \\
\text { change in } \\
\text { eosinophil } \\
\text { count }\end{array}$ & $\begin{array}{c}\text { Risk of } \\
\text { bias }\end{array}$ \\
\hline \multirow{2}{*}{ Negro et al. $(2003)^{73}$} & 10 & 44 & \multirow{2}{*}{$\begin{array}{l}\text { Mild to } \\
\text { moderate }\end{array}$} & 88.1 & 400 & \multirow{2}{*}{12 weeks } & $37.6 \%$ & $-3.2 \%$ & \multirow{2}{*}{ Unclear } \\
\hline & 10 & 47 & & 84.7 & 800 & & $44.4 \%$ & $-26.1 \% *$ & \\
\hline Wang et al. $(2005)^{74}$ & 19 & 42 & $\begin{array}{c}\text { Moderate to } \\
\text { severe }\end{array}$ & 52.4 & 1000 & 6 weeks & $6.6 \%$ & $-2.56 \%$ & High \\
\hline \multirow{2}{*}{ Lazarus et al. $(2007)^{75}$} & \multirow{2}{*}{$\begin{array}{c}44 \\
\text { (non-smoker) } \\
39 \\
\text { (smoker) }\end{array}$} & 29 & \multirow{2}{*}{ Mild } & \multirow{2}{*}{$\begin{array}{l}80.2 \\
78.1\end{array}$} & \multirow{2}{*}{320} & \multirow{2}{*}{8 weeks } & N/A & $-2.74 \% *$ & \multirow{2}{*}{ Low } \\
\hline & & 29 & & & & & N/A & $-3.44 \%^{*}$ & \\
\hline
\end{tabular}

* Statistically Significant $(\mathrm{p}<0.05)$; NS - Not significant; BD - Beclomethasone dipropionate; ICS - Inhaled corticosteroids; RCT - Randomized controlled trial; FEV1 - Forced expiratory volume in 1 second; $\mu \mathrm{g}-$ Microgram

Table 6: Summary of Mometasone ICS RCTs

\begin{tabular}{|c|c|c|c|c|c|c|c|c|c|}
\hline Author (year) & $\begin{array}{c}\text { Intervention } \\
\text { group sample } \\
\text { size }\end{array}$ & $\begin{array}{l}\text { Mean } \\
\text { Age }\end{array}$ & $\begin{array}{l}\text { Asthma } \\
\text { Severity }\end{array}$ & $\begin{array}{c}\mathrm{FEV}_{1} \% \\
\text { predicted } \\
\text { at baseline }\end{array}$ & Dose $(\mu \mathrm{g})$ & Duration & $\begin{array}{c}\text { Mean } \\
\text { baseline } \\
\text { eosinophil } \\
\text { count }\end{array}$ & $\begin{array}{c}\text { Mean } \\
\text { change in } \\
\text { eosinophil } \\
\text { count }\end{array}$ & $\begin{array}{c}\text { Risk of } \\
\text { bias }\end{array}$ \\
\hline Berry et al. $(2007)^{76}$ & 12 & 42 & N/A & 90.3 & 400 & 8 weeks & $11.0 \%$ & $-8.7 \% *$ & Low \\
\hline Nelson et al. $(2009)^{77}$ & 11 & 38 & $\begin{array}{l}\text { Mild to } \\
\text { moderate }\end{array}$ & 74.0 & 400 & 12 weeks & $2.5 \%$ & $-2.0 \%$ & Low \\
\hline
\end{tabular}

* Statistically Significant $(\mathbf{p}<0.05)$; NS - Not significant; BD - Beclomethasone dipropionate; ICS - Inhaled corticosteroids; RCT - Randomized controlled trial; FEV1 - Forced expiratory volume in 1 second; $\mu \mathrm{g}$ - Microgram 